\title{
An Investigation of the Relationship Between Cultural Orientations and Collaborative Learning and Its Implications on Higher Education
}

\author{
İbrahim ARPACI
}

\begin{abstract}
This study investigates the relationship between students' cultural orientations and their behavioral intentions for collaborative learning. A research model based on the Theory of Planned Behavior is proposed and tested in the study. The research model hypothesizes that attitudes towards and subjective norms about collaborate learning are explained by individualistic-collectivistic orientations. Structural equation modelling is used to validate the research model based on the data collected through questionnaires from 401 undergraduate students. Results suggested the collectivistic orientations are more strongly related to the attitudes towards and subjective norms about collaborative learning. The findings were discussed with reference to culture and the theory on which the study is based. Implications for both researchers and practitioners were provided.
\end{abstract}

Keywords: Culture, individualism, collectivism, collaborative learning.

\section{Kültürel Yönelimler ve İşbirlikli Öğrenme Arasındaki İlişkinin ve Bunun Yükseköğretime Yansımalarının İncelenmesi}

Öz

$\mathrm{Bu}$ çalışma, öğrencilerin kültürel yönelimleri ve işbirlikli öğrenmeye ilişkin davranışsal niyetleri arasındaki ilişkiyi incelemektedir. Bu bağlamda, Planlı Davranış Teorisi temel alınarak bir araştırma modeli önerilmiş ve çalışmada test edilmiştir. Araştırma modeli, işbirlikli öğrenmeye yönelik tutum ve öznel normların bireycilik-toplulukçuluk yönelimleri ile açıklanabileceğini varsaymaktadır. Araştırma modelinin doğrulaması için 401 üniversite öğrencisinden anket yöntemiyle toplanan veriler yapısal eşitlik modellemesi kullanılarak analiz edilmiştir. Sonuçlar, toplulukçuluk yönelimleri ile işbirlikli öğrenmeye yönelik tutum ve öznel normlar arasında daha güçlü bir ilişki önermektedir. Bulgular, kültüre ve çalışmanın temellendirildiği teoriye istinaden tartışılmıştır. Araştırmacı ve uygulamacılara yönelik öneriler sunulmuştur.

Anahtar Kelimeler: Kültür, bireycilik, toplulukçuluk, işbirlikli öğrenme.

\footnotetext{
*Yrd. Doç. Dr., Gaziosmanpasa University, ibrahim.arpaci@gop.edu.tr
} 


\section{INTRODUCTION}

Culture has several definitions, for example, Triandis (1995, p.22) defines culture as "a set of objective and subjective perceptions." However, Hall (1976, 1983) defines culture as a "subconscious mechanism" while Hofstede, Hofstede, and Minkov (2010, p.3) define it as "the collective programming of the mind that distinguishes the members of a group or category of people from others." On the other hand, other studies suggest that it includes more observable and explicit cultural artifacts such as rituals, language, ceremony, myths, and ideology (Pettigrew, 1979; Karahanna, Evaristo, \& Srite, 2005), practices and norms (Jermier, Slocum, Fry, \& Gaines, 1991), as well as symbols (Burchell, Clubb, Hopwood, Hughes, \& Nahapiet, 1980). However, in this study, culture is conceptualized as "a system of values, norms, and beliefs that affect attitudes, subjective norms, and in turn, behaviors" (Arpaci \& Baloğlu, 2016).

Culture may have a positive effect on students' attitudes and behavioral intentions toward collaboration or collaborative learning. Collaboration can be defined as "a coordinated, synchronous activity that is the result of a continued attempt to construct and maintain a shared conception of a problem", while collaborative learning involves the "mutual engagement of participants in a coordinated effort to solve the problem together" (Roschelle \& Teasley, 1995, p. 70). In this study, collaboration is understood as "a process in which students acquire knowledge through co-participating, cocognizing, and co-problem-solving within linguistically, culturally, and academically heterogeneous groups throughout the course of task completion" (Gutiérrez, BaquedanoLópez, Alvarez, \& Chie, 1999, p. 3).

However, cultural characteristics should be conceptualized and identified in order to un- derstand the effects of cultural orientations on students' attitudes and behaviors. Accordingly, several models and taxonomies of national culture have introduced to provide a common and comparable frame of reference. For example, Hofstede (1980) suggested a model, which explain cultural differences and the consequences, in four dimensions, including "power distance, individualism-collectivism, masculinity-femininity, and uncertainty avoidance" (Arpaci \& Baloğlu, 2016).

Hofstede (1980) define power distance as "the extent to which a society accepts that power in institutions and organizations is distributed unequally." Masculinity versus Femininity defined as "the extent to which dominant values in society are assertiveness, money, and material things, as opposed caring for others, quality of life, and people" (Hofstede, 1980). Uncertainty avoidance can be defined as "the extent to which a society feels threatened by uncertain or ambiguous situations" (Hofstede, 1980). Later on, Hofstede's cultural model was extended with two extra dimensions; short term and long term orientations (Hofstede \& Bond, 1988) and indulgence versus restraint (Hofstede et al., 2010). Long-term orientation defined as "the extent to which a society shows a pragmatic future-oriented perspective rather than a conventional historical short-term point of view" (Hofstede \& Bond, 1988). Whereas, indulgence versus restraint defined as "the extent to which member in society try to control their desires and impulses" (Hofstede et al., 2010).

Similarly, Smith and Schwartz (1997) identified three dimensions of national culture; hierarchyegalitarianism, conservatism-autonomy, and mastery-harmony. Conservatism-autonomy reflects socio-centric values (i.e., tradition, conformity, and security) versus intellectual autonomy (i.e., creativity, independence, and 
independent mind) and affective autonomy (i.e., exciting and pleasure). This dimension is correlated with Hofstede's individualismcollectivism (Lowe, 2001). In another study, Trompenaars and Hampden-Turner (1993) suggested another cultural model having seven dimensions, including affective-neutral, individualism-communitarianism, achievementascription, universalism-particularism, specificdiffuse cultures, relation to nature, and time perception. The definition of individualismcommunitarianism also coincides with Hofstede's description of individualismcollectivism. Parsons and Shils (1951) define individualism as "prime orientation to the self", and communitarianism as "prime orientation to common goals and objectives."

Taken together, several studies on culture suggest that individualism-collectivism dimension of culture is one of the main determinants of cultural values (Triandis, 1995; Hofstede et al., 2010; Trompenaars \& Hampden-Turner, 1993; Kim, Triandis, Kâğıtçıbaşı, Choi, \& Yoon, 1994). Indeed, individualism-collectivism constitutes one of the most significant dimensions of culture in social behavior (İmamoğlu, 1998; Kâğıtçıbaşı, 1987). Further, dominant individualistic and collectivistic values in a society are reported as the main reason for cultural differences in self-construal (Kitayama \& Cohen, 2010; Hofstede, 2001; Kâğıtçıbaşı, 2002; Triandis, 2001; İmamoğlu, 1998).

The effects of the cultural values, specifically individualistic and collectivistic orientations, on human behavior have been a major theme of recent literature (Arpaci \& Baloğlu, 2016). However, there is a limited number of studies on the effect of individuals' cultural orientations on their preferences of learning style. Previously, Hutchinson and Gul (1998) identified the significant impacts of introversionextroversion personality traits and collec- tivistic-individualistic orientations on the students' group learning preferences. This study suggested that cultural orientations have significantly affect students' choice of learning. Given that, this study investigates the relationships between collectivistic-individualistic orientations and collaborative learning and its implications on higher education. Thus, the present study proposes and tests a research model based on the Theory of Planned Behavior (TPB, Fishbein \& Ajzen, 1975).

\section{RESEARCH MODEL AND HYPOTH- ESES}

This study used the TPB, which is a widely accepted theory in predicting attitudes and behaviors (Armitage \& Conner, 2001), as a theoretical framework. This theory suggests that "a behavior is predicted by intentions, and that the intentions are jointly determined by attitudes and subjective norms about the behavior" (Fishbein \& Ajzen, 1975). Accordingly, the present study suggests that students' behavioral intentions for collaborative learning are explained by their attitudes and subjective norms. It also suggests the students' attitude and subjective norms are explained by the cultural value orientations; individualismcollectivism.

\subsection{Collectivism versus Individualism}

Collectivism is defined as "the subordination of personal goals to the goal of the group with an emphasis on sharing and group harmony", while individualism is defined as "an individual's self-orientation that emphasizes selfsufficiency and control with value being given to self-accomplishments" (Morris, Davis, \& Allen, 1994). Turkey has a collectivistic culture, where individuals are integrated into groups (Hofstede, 2001). However, individuals can have both individualistic and collectivistic 
values (İmamoğlu, 2003; Kâğıtçıbaşı, 1990). In the same vein, Triandis (2001) argues that collectivism and individualism are not necessarily opposites on a continuum, but rather uncorrelated constructs in which individuals may possess characteristics of collectivism and individualism simultaneously at low or high levels.

Individuals with high collectivistic orientations are linked to a social group and sacrificed their personal interests for the group, which "throughout people's lifetime continue to protect them in exchange for unquestioning loyalty" (Hofstede, 1980). Therefore, it's more important for the students with high collectivistic orientations to consider the interest of their group before themselves. This suggests that collectivistic orientations might have a stronger impact on the attitudes towards collaborative learning than those of individualistic orientations. Therefore:

H1. Collectivistic orientations would be more strongly related to attitudes toward collaborative learning.

As individuals with high collectivistic orientations emphasis on the group and family, they need to consult with their group and family before taking a decision or acting. Therefore, individuals with high collectivistic orientations might be more likely to be affected by the opinions of their group and family members. This suggests that collectivistic orientations might have a stronger impact on subjective norms about collaborative learning than those of individualistic orientations. Accordingly:

H2. Collectivistic orientations would be more strongly related to subjective norms about collaborative learning.

\subsection{Attitude}

Attitude towards collaborative learning can be defined as "the degree of a student's positive or favorable feeling about" collaborative learning in groups (Arpaci \& Baloğlu, 2016, p. 67). However, behavioral intention for collaborative learning can be defined as "the degree of a student's beliefs that she or he will engage in" collaborative learning (Arpaci \& Baloğlu, 2016, p. 67). Attitudes towards a behavior are significant predictors of behavioral intentions to engage in that behavior. Therefore:

H3. Attitudes towards collaborative learning would be positively related to behavioral intentions.

\subsection{Subjective Norm}

Subjective norm can be defined as "the perceived social pressure to perform or not to perform a behavior" (Ajzen 1991, p. 188). The students who perceives greater social pressures would have stronger behavioral intentions for collaborative learning. This means that the more favorable the subjective norms with respect to collaborative learning the stronger would be the behavioral intention to learn collaborating with peers. Accordingly:

H4. Subjective norms about collaborative learning would be positively related to behavioral intentions.

\section{METHOD}

This study employed quantitative methods to investigate the causal relationships existing between cultural orientations and collaborative learning. Statistical software used in this study included SPSS (version 22; IBM Inc., Chicago, IL) and Analysis of Moment Structures (AMOS version 22, IBM Inc., Armonk, NY). AMOS was used to estimate the relationship between the exogenous and endogenous constructs and for the confirmatory factor analysis. 


\subsection{Sample}

A total of 401 undergraduate students, who are selected by using convenience sampling, willingly participated in this study and completed an Internet based survey. Respondents' ages ranged from 18 to 33 years. Mean age was 20.62 $(S D=2.41)$. Of the total 401 students, $60.8 \%$ of the respondents are female $(n=244)$, while $39.2 \%(n=157)$ are male. Moreover, $52.9 \%$ of the respondents are from the first year cohort, while $10 \%$ are from the second year cohort, followed by $14.5 \%$ from the third year, and $22.6 \%$ from the fourth year.

\subsection{Instrument}

Singelis, Triandis, Bhawuk, \& Gelfand (1995) designed a scale called "INDCOL" to measure individualistic-collectivistic orientations at the individual level. Turkish version of this scale was translated and validated by Wasti and Erdil (2007). The items related to individualism-collectivism were adapted from this scale. The validity and reliability evidence of the adapted scale was satisfactory (Wasti \& Erdil, 2007). Further, the Cronbach's alpha internal consistency coefficient for the scale was .97 for the present sample. The items measuring subjective norm, attitude, and behavioral intentions were adapted from the TPB (Fishbein \& Ajzen, 1975; Ajzen, 1991). The instrument used in the study has a total of 34 items, including 10 items for collectivism, 10 items for individualism, seven items for attitude, three items for subjective norm, and four items for behavioral intention. The participants are asked to rate their level of agreement with 34 items by using a five-point Likert scale ranging from 1 (strongly disagree) to 5 (strongly agree).

\section{RESULTS}

\subsection{Validity and reliability}

The data set was checked for suitability for factor analysis prior to conducting an exploratory factor analysis (EFA). Table 1 indicates the suitability of the data for factor analysis. The results of Kaiser-Meyer-Olkin (KMO) tests along with Bartlett's test of Sphericity verified sampling adequacy of the data for factorability (Bartlett, 1951; Kaiser, 1970).

Table 1. Suitability of the data set for factor analysis

\begin{tabular}{llll}
\hline & KMO & Chi-Square & Sig. \\
\hline Collectivism & .96 & 3743.94 & .001 \\
Individualism & .91 & 2725.03 & .001 \\
Attitude & .93 & 3234.93 & .001 \\
Subjective Norm & .74 & 650.48 & .001 \\
Behavioral Intention & .85 & 1704.68 & .001 \\
\hline
\end{tabular}

In total, seven measurement items were excluded from the scale according to the EFA. Therefore, 27 questionnaire items were subjected to an EFA, which was conducted using principal components extraction. The Bartlett's test of Sphericity showed that the measures for five constructs were inter-dependent. Furthermore, the KMO measure of sampling adequacy was well above the accepted level of .50 (Leech, Barrett, \& Morgan, 2005).

A one factor solution seemed to be most suitable for each of the measurement on the basis of a scree-plot of eigenvalues. Total variance explained ranged between 80.84 and 88.66 , which were far higher than acceptable value of .40 (Scherer, Wiebe, Luther, \& Adams, 1988). Fur- 
thermore, each measurement item has a factorloading above .83 , which is far higher than the acceptable value of .40 (Field, 2005). This ensures that factor structures were robust. In addition, minimum communality value was .70, which is far higher than the acceptable value of .30. The corrected item total correlation coefficients ranged from .74 to .95 , indicating high homogeneity of the scale items; according to Hair, Tatham, Anderson, \& Black (2006) more than .50 is considered ideal. Further, the item analysis suggested that the measurement items can reliably discriminate the subjects.

The results of the reliability analysis showed that the instrument has a strong internal consistency with the Cronbach's alpha values ranged from .88 to .97 (Creswell, 2005). The results of the principal component analysis and internal consistency reliability measures were provided in Table 2.

Table 2. Validity and reliability

\begin{tabular}{|c|c|c|c|c|c|c|}
\hline Item & 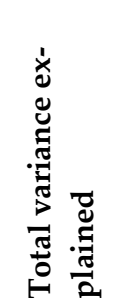 & 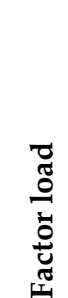 & 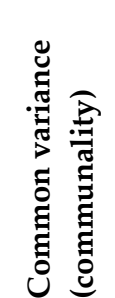 & 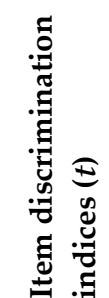 & 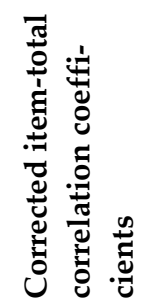 & 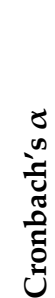 \\
\hline Collectivism & 81.07 & & & & & .97 \\
\hline $\mathrm{C} 2$ & & .84 & .70 & $17.65^{*}$ & .79 & \\
\hline $\mathrm{C} 3$ & & .86 & .74 & $23.71^{*}$ & .82 & \\
\hline C4 & & .93 & .86 & $34.35^{*}$ & .91 & \\
\hline C5 & & .95 & .90 & $41.00^{*}$ & .93 & \\
\hline C6 & & .91 & .83 & $28.06^{*}$ & .88 & \\
\hline $\mathrm{C} 7$ & & .89 & .80 & $25.60^{*}$ & .86 & \\
\hline $\mathrm{C} 8$ & & .92 & .85 & $36.05^{*}$ & .90 & \\
\hline C9: I feel good when I cooperate with others. & & .89 & .77 & $27.46^{*}$ & .86 & \\
\hline Individualism & 88.66 & & & & & .97 \\
\hline I1: Being a unique individual is important to me. & & .94 & .88 & $43.88^{*}$ & .91 & \\
\hline $\mathrm{I} 2$ & & .97 & .93 & $19.01^{*}$ & .95 & \\
\hline I3 & & .93 & .87 & $9.49^{*}$ & .90 & \\
\hline $\mathrm{I} 4$ & & .96 & .93 & $26.65^{*}$ & .94 & \\
\hline I5 & & .90 & .82 & $39.94^{*}$ & .85 & \\
\hline Subjective Norm & 80.84 & & & & & .88 \\
\hline $\begin{array}{l}\text { SN1: People who are important to me think that } \\
\text { I should learn collaborating with my friends. }\end{array}$ & & .88 & .78 & $16.78^{*}$ & .74 & \\
\hline SN2 & & .92 & .84 & $21.99 *$ & .80 & \\
\hline SN3 & & .90 & .81 & $25.97^{*}$ & .77 & \\
\hline Attitude & 81.87 & & & & & .96 \\
\hline A1 & & .84 & .77 & $27.87^{*}$ & .83 & \\
\hline $\begin{array}{l}\text { A2: I prefer to learn through collaboration rather } \\
\text { than to learn alone. }\end{array}$ & & .85 & .79 & $26.01^{*}$ & .85 & \\
\hline $\mathrm{A} 3$ & & .83 & .77 & $24.86^{*}$ & .83 & \\
\hline A4 & & .87 & .84 & $26.19^{*}$ & .88 & \\
\hline A5 & & .90 & .88 & $31.95^{*}$ & .91 & \\
\hline A6 & & .89 & .85 & $31.32^{*}$ & .89 & \\
\hline A7 & & .87 & .85 & $36.77^{*}$ & .89 & \\
\hline
\end{tabular}




\begin{tabular}{lccccc}
\hline Behavioral Intention & 87.61 & & & & .95 \\
\hline BI1: I will learn by collaborating with my friends & .93 & .86 & $26.94^{*}$ & .87 \\
more frequently in the future. & & & & \\
BI2 & .95 & .91 & $23.53^{*}$ & .92 \\
BI3 & .93 & .86 & $21.47^{*}$ & .87 \\
BI4 & .94 & .88 & $23.33^{*}$ & .88 \\
\hline
\end{tabular}

${ }^{*} \mathrm{p}<.001$

\subsection{Confirmatory factor analysis}

A structural equation modelling (SEM) was conducted via maximum likelihood by using SPSS AMOS (v.22; IBM Corp. Released 2013, Armonk, NY, USA) to validate the model based on the data collected from 232 university students. The effects of collectivistic and individu- alistic orientations on attitudes and subjective norms were investigated in Model 1 and Model 2 , respectively. Both models produced good fit indices as presented in Table 3. Results from the confirmatory factor analysis indicated all of the scales formed adequate measurement models and therefore provided evidence for the construct validity.

Table 3. Model Fit Indices

\begin{tabular}{llll}
\hline & Model 1 & Model 2 & Acceptable Fit Values \\
\hline$\chi^{2}$ & 256.119 & 247.277 & \\
$p$ value & $<.001$ & $<.001$ & $.05 \leq p \leq 1.00$ (Hoyle, 1995) \\
$\chi^{2} / \mathrm{df}$ & 2.07 & 1.74 & $<3$ (Kline, 2005) \\
GFI & .90 & .90 & $\geq .90$ (Hair et al., 2006) \\
AGFI & .86 & .86 & $\geq .80$ (Marsh, Balla, \& McDonald, 1988) \\
SRMR & .12 & .07 & $\leq .10$ (Kline, 2005) \\
RMR & .13 & .06 & $<.05$ (McDonald \& Moon-Ho, 2002) \\
RMSEA & .07 & .06 & $<.08$ (Hair et al., 2006) \\
NFI & .91 & .92 & $\geq .90$ (Hair et al., 2006) \\
NNFI & .94 & .96 & $\geq .90$ (Bentler \& Bonett, 1980) \\
CFI & .95 & .97 & $\geq .90$ (Bentler, 1990) \\
IFI & .95 & .97 & $\geq .90$ (Bollen, 1989) \\
PNFI & .74 & .77 & \\
\hline
\end{tabular}

Possible misspecifications, as suggested by the modification indices, were searched for, and a revised, re-specified model was fitted to the data. For Model 1, the value of chi-square/df is 2.07, a ratio of less than 1.5 is considered to be very good (Kline, 2005), while a ratio of less than 3.0 is good (Sümer, 2000). The GFI and AGFI are .90 and .86 , respectively. The NNFI is .94 and the NFI has a value of .91. The CFI and IFI have a value of .95 , both exceed the threshold ( $\geq .90)$ for acceptable fit. Lastly, the RMSEA is .07 , which is below the acceptable level of .08 . Altogether, the Model 1 fits the data reasonably well.
The goodness of fit indices for Model 2 were: $\left[\chi^{2} / \mathrm{df}=1.74, \mathrm{GFI}=.90, \mathrm{AGFI}=.86, \mathrm{NNFI}=.96\right.$, $\mathrm{NFI}=.92, \mathrm{CFI}=.97, \mathrm{IFI}=.97$, RMSEA=.06]. Examination of overall goodness of fit indices for Model 2 indicated a relatively better fit between the hypothesized model and the observed data.

\subsection{Structural models}

SEM using AMOS was employed to identify and estimate the structural relationships. Consistent with the hypotheses, the results showed that all proposed paths among the latent variables were significant. Figure 1 and 2 demon- 
strate the results of the SEM analysis for individualism and collectivism, respectively. It is important to note the regression weights for collectivism and individualism in the prediction of behavioral intention were not significantly different from zero at the .05 level.

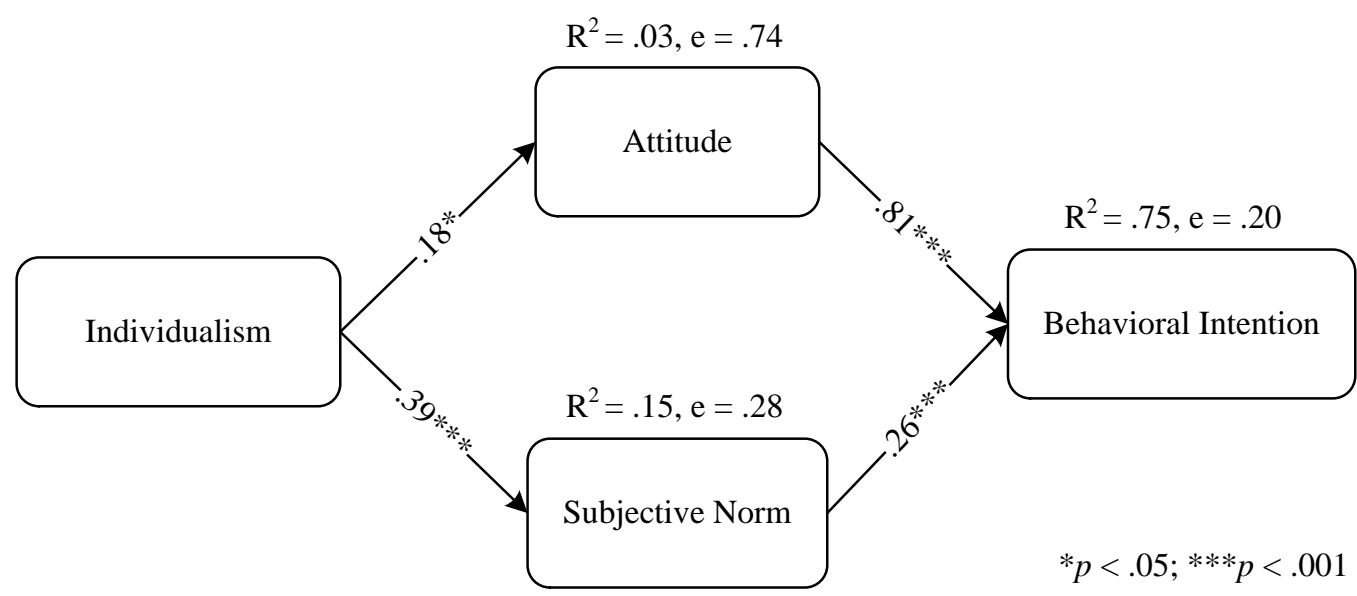

Chi-Square $=256.119, \mathrm{df}=124, \mathrm{Chi}-$ Square $/ \mathrm{df}=2.07, P$-value $=.000, \mathrm{GFI}=.90, \mathrm{RMSEA}=.07$

Figure 1. The structural equation model for individualism

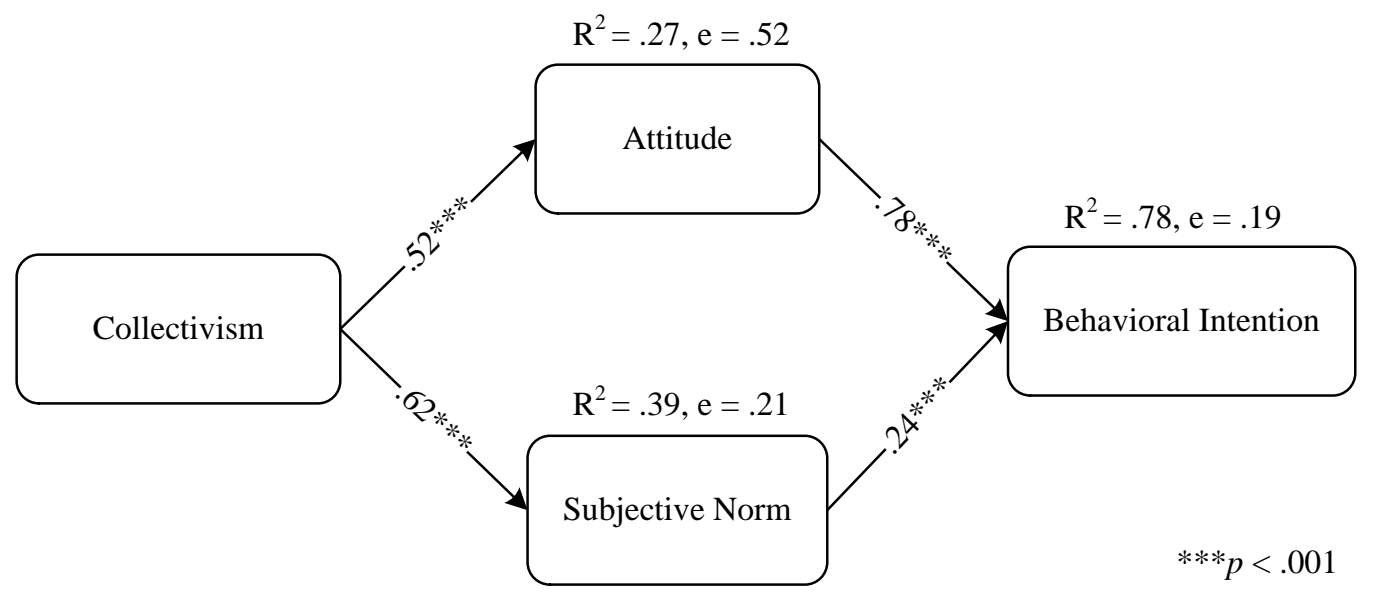

Chi-Square $=247.277, \mathrm{df}=142, \mathrm{Chi}-$ Square $/ \mathrm{df}=1.74, P$-value $=.000, \mathrm{GFI}=.90, \mathrm{RMSEA}=.06$

Figure 2. The structural equation model for collectivism

\subsection{Hypothesis Testing}

Summary of the hypothesis testing results is as follows:

H1. Collectivistic orientations would be more strongly related to attitudes toward collaborative learning $\left(\beta_{1}=.18 ; t_{1}=2.33 ; \beta_{2}=.52 ; t_{2}=5.71\right)$.
H2. Collectivistic orientations would be more strongly related to subjective norms about collaborative learning $\left(\beta_{1}=.39 ; t_{1}=4.26 ; \beta_{2}=.62\right.$; $\left.t_{2}=5.62\right)$. 
H3. Attitudes towards collaborative learning would be positively related to behavioral intentions $\left(\beta_{1}=.81 ; t_{1}=13.23 ; \beta_{2}=.78 ; t_{2}=12.60\right)$.

H4. Subjective norms about collaborative learning would be positively related to behavioral intentions $\left(\beta_{1}=.26 ; t_{1}=5.24 ; \beta_{2}=.24 ; t_{2}=4.91\right)$.

\section{DISCUSSION AND CONCLUSION}

The present study investigated the relationships between students' cultural orientations and their behavioral intentions for collaborative learning. Based on the TPB, this study developed a research model that posits the students' attitude and subjective norms are explained by their individualistic-collectivistic orientations and behavioral intentions are explained by the attitudes and subjective norms. The proposed model, which explains $75 \%$ of the variance in intentions has a strong predictive power. These findings revealed the importance of cultural orientations in predicting attitudes and subjective norms, and in turn, behavioral intentions. Moreover, the findings justified the integration of this variable within the TPB, and thereby, extended this framework.

This study hypothesized that collectivistic orientations would be more strongly related to the attitudes and subjective norms toward collaborative learning than those of individualistic orientations. The results along with prior studies supported these hypotheses. Previous studies suggested a strong link between culture and learning as well (Cole, Jay, Glick \& Sharp, 1971; Berry, 1976; Swisher \& Deyhle, 1989; Cooper, 1980; Banks, 1988; Anderson, 1988; More, 1990). For example, Hickson, Land, and Aikman (1994) investigated the differences in learning style among ethnic populations and possible ways to accommodate the differences to enhance student success. Their results showed the learning styles of different ethnic groups are significantly discriminated. In a similar study, Joy and Kolb (2009) investigated the effect of individual culture dimensions in shaping the learning style preferences and found that individuals tend to have more abstract learning styles in societies that are high in institutional and in group collectivism, uncertainty avoidance, future orientation, and gender egalitarianism. On the other hand, individuals tend to have more reflective learning styles in societies that are high in in group collectivism, assertiveness, and uncertainty avoidance.

In another study, Yamazaki (2005) investigated the relationships between the typologies of cultural differences and learning styles of Kolb's (2005) learning model. Results suggested that each particular culture related to certain abilities or learning styles. Similarly, Olaniran (2009) suggested that learners with high collectivistic orientations prefer increased level of control or direction from teachers, whereas the learners with high individualistic orientations prefer greater autonomy in the learning environments.

This study has a number of implications for both researchers and practitioners. First of all, the students' cultural orientations should be taken into account while planning instructional methods and learning models. The findings indicated the students with a high collectivistic orientation were more willing to learn collaborating with peers and open to collaboration. This suggests that educators should adopt proper instructional techniques. For example, employing collaborative learning in which team members work together on a problem or a project can be a suitable technique for these students. By this way, the students may learn through co-participating, co-problem-solving, and co-cognizing. Moreover, they may learn in 
social interaction developing co-cognition and high-level cognitive skills.

Further, instructors can prefer contemporary learning models such as constructivism, collaboratism, and socio-culturism in which teachers' main role is serving as a facilitator for providing scaffolding and continuous support in the learning process but not transmitting information. By this way, the students would take the initiative for their own learning process, and thereby, they would improve their problem solving and critical thinking skills. Moreover, educational institutions may employ social networks and collaborative environments such as cloud computing services, communities of practices, and virtual learning environments that facilitate knowledge sharing and help students learn together.

Finally, the present study has some limitations. Since data collection was restricted to the individuals in a collectivistic society, the findings should be applied to individuals in different cultures with caution. Further research may recruit participants from diverse societies for better understanding of cross cultural differences. Lastly, it could be worthwhile to use both qualitative as well as quantitative research approaches for better understanding of how cultural orientations affect collaborative learning.

\section{References}

Ajzen, I. (1991). The theory of planned behavior. Organizational Behavior and Human Decision Processes, 50(2), 179-211.

Anderson, J. A. (1988). Cognitive styles and multicultural populations. Journal of Teacher Education, 39(1), $2-9$.

Armitage, C. J., \& Conner, M. (2001). Efficacy of the theory of planned behavior: A meta-analytic review. British Journal of Social Psychology, 40(4) 471-499.

Arpaci, I., Baloğlu, M. (2016). The impact of cultural collectivism on knowledge sharing among information technology majoring undergraduates. Computers in Human Behavior, 56(3), 65-71. Doi: 10.1016/j.chb.2015.11.031.

Banks, J. A. (1988). Ethnicity, class, cognitive, and motivational styles: Research and teaching implications. Journal of Negro Education, 57(4), 452-466.

Bartlett, M. S. (1951). The effect of standardization on a $\chi 2$ approximation in factor analysis. Biometrika, $38(3 / 4), 337-344$.

Bentler, P. M. (1990). Comparative fit indexes in structural models. Psychological Bulletin, 107, 238-246.

Bentler, P. M., \& Bonett, D. G. (1980). Significance tests and goodness-of-fit in the analysis of covariance structures. Psychological Bulletin, 88, 588-606.

Berry, J. W. (1976). Human ecology and cognitive style: Comparative studies in psychological adaptation. New York: Sage-Halstead.

Bollen, K. A. (1989). Structural equations with latent variables. New York: Wiley. 
Burchell, S., Clubb, C., Hopwood, A., Hughes, J., \& Nahapiet, J. (1980). The roles of accounting in organizations and society. Accounting, Organizations and Society, 5(1), 5-27.

Cole, M., Gay, J., Glick, J, \& Sharp, D. W. (1971). The cultural context of learning and thinking. New York: Basic Books.

Cooper, G. (1980). Different ways of thinking. Minority Education, 2(5), 1-4.

Creswell, J. W. (2005). Educational research: Planning conducting and evaluating quantitative and qualitative approaches to research (2nd Ed.). Upper Saddle River, NJ: Merrill/Pearson Education.

Field, A. (2005). Discovering statistics using SPSS. Thousand Oaks, CA: SAGE.

Fishbein, M., \& Ajzen, I. (1975). Belief, attitude, intention and behavior: An introduction to theory and research. Reading, MA: Addison-Wesley.

Gutiérrez, K. D., Baquedano-López, P., Alvarez, H. H., \& Chiu, M. M. (1999). Building a culture of collaboration through hybrid language practices. Theory into Practice, 38(2), 87-93.

Hair, J. F., Tatham, R. L., Anderson, R. E., \& Black, W. (2006). Multivariate data analysis (6th Ed.). Upper Saddle River, NJ: Pearson Prentice Hall.

Hall, E. (1976). Beyond culture. New York: Anchor Press.

Hall, E. (1983). The dance of life: The other dimension of time. Garden City: Anchor Press/Doubleday.

Hickson, J., Land, A. J., \& Aikman, G. (1994). Learning style differences in middle school pupils from four ethnic backgrounds. School Psychology International, 15(4), 349-359.

Hofstede, G. (1980). Culture's consequences: International differences in work-related values. Beverly Hills and London: Sage Publications.

Hofstede, G. (2001). Culture's consequences: Comparing values, behaviors, institutions, and organizations across nations (2nd Ed.). Thousand Oaks: Sage Publications.

Hofstede, G., \& Bond, M. H. (1988). The Confucius connection from cultural roots to economic growth. Organizational Dynamism, 16(4), 4-18.

Hofstede, G., Hofstede, G. J., \& Minkov, M. (2010). Cultures and organizations: Software of the mind: Intercultural cooperation and its importance for survival. McGraw-Hill USA, New York.

Hoyle, R. H. (1995). The structural equation modeling approach: Basic concepts and fundamental issues. In Structural equation modeling: Concepts, issues, and applications, R. H. Hoyle (editor). Thousand Oaks, CA: Sage Publications, Inc., pp. 1-15.

Hutchinson, M., \& Gul, F. A. (1998). The interactive effects of extroversion/introversion traits and collectivism/individualism cultural beliefs on student group learning preferences. Journal of Accounting Education, 15(1), 95-107.

İmamoğlu, E. O. (1998). Individualism and collectivism in a model and scale of balanced differentiation and integration. The Journal of Psychology, 132(1), 95-105.

İmamoğlu, E. O. (2003). Individuation and relatedness: Not opposing but distinct and complementary. Genetic, Social, and General Psychology Monographs, 129(4), 367-402. 
Jermier, J. M., Slocum Jr, J. W., Fry, L. W., \& Gaines, J. (1991). Organizational subcultures in a soft bureaucracy: Resistance behind the myth and facade of an official culture. Organization science, 2(2), 170-194.

Joy, S., \& Kolb, D. A. (2009). Are there cultural differences in learning style? International Journal of Intercultural Relations, 33(1), 69-85.

Kâğıtçıbaşı, Ç. (1987). Individualism and collectivism, a universal dimension? In Kâğıtçıbaşı, Ç. (Ed.), Growth and progress in cross-cultural psychology (pp. 76-77). Lisse, Holland: Swets \& Zeitlinger.

Kâğıtçıbaşı, Ç. (1990). İnsan-Aile-Kültür. İstanbul: Remzi Kitabevi.

Kâğıtç̧ıaşı, C. (2002). Psychology and human competence development. Applied Psychology, 51(1), 5-22.

Kâğıtçıbaşı, C. (2005). Autonomy and relatedness in cultural context implications for self and family. Journal of Cross-Cultural Psychology, 36(4), 403-422.

Kaiser, H. F. (1970). A second generation little jiffy. Psychometrika, 35(4), 401-415.

Karahanna, E., Evaristo, J. R., \& Srite, M. (2006). Levels of culture and individual behavior: An integrative perspective. Journal of Global Information Management, 13(2), 1-20.

Kim, U. E., Triandis, H. C., Kâğıtçıbaşı, Ç. E., Choi, S. C. E., \& Yoon, G. E. (1994). Individualism and collectivism: Theory, method, and applications. Thousand Oaks, CA, US: Sage Publications.

Kitayama, S., \& Cohen, D. (Eds.). (2010). Handbook of cultural psychology. Guilford Press.

Kline, R. B. (2005). Principles and practice of structural equation modeling (2nd Ed.). New York: The Guilford Press.

Kolb, A. Y., \& Kolb, D. A. (2005). Learning styles and learning spaces: Enhancing experiential learning in higher education. Academy of Management Learning \& Education, 4(2), 193-212.

Leech, N. L., Barrett, K. C., \& Morgan, G. A. (2005). SPSS for intermediate statistics: Use and interpretation (2nd Ed.). Hillsdale, NJ: Lawrence Erlbaum.

Marsh, H. W., Balla, J. R., \& McDonald, R. P. (1988). Goodness-of-fit indexes in confirmatory factor analysis: The effect of sample size. Psychological bulletin, 103(3), 391-410.

McDonald, R. P., \& Moon-Ho, R. H. (2002). Principles and practice in reporting structural equation analysis. Psychological Methods, 7(1), 64-82.

More, A. J. (1990). Learning Styles of Native Americans and Asians. Paper presented at the Annual Meeting of the American Psychology Association (98th, Boston, MA, August 13, 1990).

Morris, M. H., Davis, D. L., \& Allen, J. W. (1994). Fostering corporate entrepreneurship: Cross-cultural comparisons of the importance of individualism versus collectivism. Journal of International Business Studies, 25, 65-89.

Olaniran, B. A. (2009). Culture, learning styles, and Web 2.0. Interactive Learning Environments, 17(4), 261271.

Parsons, T., \& Shils, E. A. (1951). Towards a general theory of action. Harvard University Press, Cambridge, MA. 
Roschelle, J. \& Teasley S. D. (1995). The construction of shared knowledge in collaborative problem solving. In C. E. O’Malley (Ed.), Computer-Supported Collaborative Learning (pp. 69-197). Berlin: Springer-Verlag.

Scherer, R. F., Wiebe, F. A., Luther, D. C., \& Adams, J. S. (1988). Dimensionality of coping: Factor stability using the ways of coping questionnaire. Psychological Reports, 62, 763-770.

Singelis, T. M., Triandis, H. C., Bhawuk, D. P., \& Gelfand, M. J. (1995). Horizontal and vertical dimensions of individualism and collectivism: A theoretical and measurement refinement. Crosscultural Research, 29(3), 240-275.

Smith, P. B. \& Schwartz, S. H. (1997). Values. In Berry J. W., Segall M. H., \& Kâğıtçıbaşı, C. (Eds.), Social Behavior and Applications: Handbook of Cross-Cultural Psychology, 3(2), Boston: Allyn and Bacon.

Sümer, N. (2000). Yapısal eşitlik modelleri: Temel kavramlar ve örnek uygulamalar. Türk Psikoloji Yazıla$r l, 3(6), 49-74$.

Swisher, K., \& Deyhle, D. (1989). The Styles of Learning Are Different, but the Teaching Is Just the Same: Suggestions for Teachers of American Indian Youth. Journal of American Indian Education, Special Issue, 1-14.

Triandis, H. C. (1995). Individualism and collectivism. Boulder, CO: Westview Press.

Triandis, H. C. (2001). Individualism and collectivism: Past, present, and future. In D. Matsumoto (Ed.), the handbook of culture and psychology (pp. 35-50). Oxford: Oxford University Press.

Trompenaars, A. \& Hampden-Turner, C. (1993). Riding the waves of culture: Understanding cultural diversity in business. London: Nicholas Brealey.

Yamazaki, Y. (2005). Learning styles and typologies of cultural differences: A theoretical and empirical comparison. International Journal of Intercultural Relations, 29(5), 521-548. 